\title{
HUBUNGAN ANTARA PENGAMBILAN KEPUTUSAN DENGAN PERILAKU KONTRAPRODUKTIF GURU SMP NEGERI DI KOTA BEKASI (BEKASI, 2017)
}

\author{
Bella Meilia Saputra, Dr. Dwi Deswary, M.Pd, Dr. Eliana Sari, MM
}

\section{bellameimeilia@gmail.com}

\begin{abstract}
This study aims to determine the relationship between decision making and counterproductive behavior Junior High School teacher in Bekasi. The method used is survey method with the correlational studies and quantitative approaches. Samples were as many as 94 teachers. Sampling using simple random sampling by the formula Slovin and data collection using the questionnaires. From the results of the hypothesis testing, obtained $t_{\text {count }}$ equal to 2,10, which means bigger than $t_{\text {table }} 1,986$. Thus, the alternative hypothesis ( $\mathrm{Ha}$ ) are accepted positively. Of the coefficient of determination, decisionmaking contributed $4.57 \%$ to the counterproductive behavior Junior High School teacher in Bekasi. Based on the results of the survey results revealed that more favorable decision, the lower the level of counterproductive behavior Junior High School teacher in Bekasi.
\end{abstract}

Keywords: Decision-Making, Counterproductive Behavior

\section{Pendahuluan}

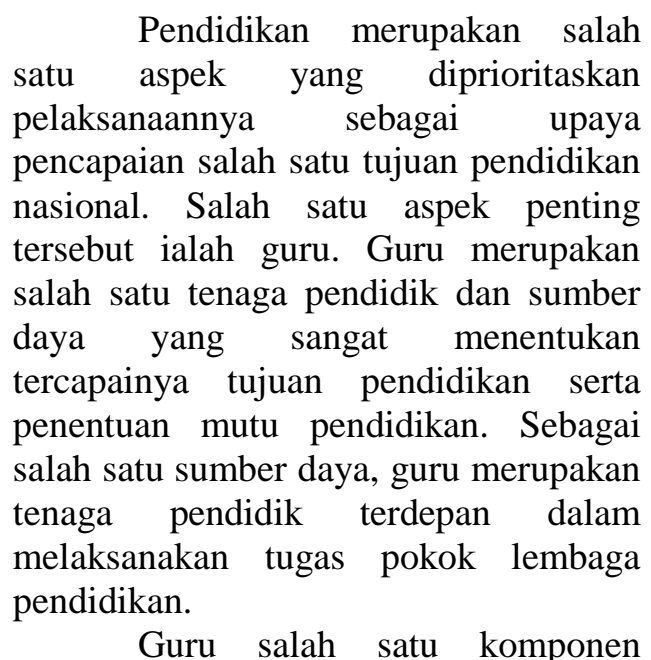
terpenting dalam pendidikan, dimana guru memegang peranan yang sangat vital dalam penyelenggaraan pendidikan formal pada khususnya. Demi terselenggaranya pendidikan yang baik, guru sebagai bagian didalamnya dituntut untuk memiliki kualifikasi sesuai dengan standar yang telah ditetapkan pemerintah serta menguasai kompetensi pedagogik, profesionalisme, kepribadian dan sosial seperti yang diatur dalam Permendiknas No. 16 Tahun 2007 tentang Standar Kualifikasi Akademik dan Kompetensi Guru.

Perilaku tidak baik juga salah satunya terjadi di kota bekasi. Guru yang seharusnya profesional dan taat pada aturan yang telah dibuat oleh pemerintah itu dilanggar dengan ketidaksengajaannya. Hal tersebut disampaikan oleh Bapak Teguh Widodo selaku Kasubag kepegawaian Kantor Dinas Pendidikan kota Bekasi pada tanggal 28 September 2016 pukul 14:00. Beliau mengatakan bahwa :

Masih ada guru yang tertangkap atau terlihat di sekitaran pusat perbelanjaan di kota bekasi pada saat jam kerja, meskipun jam mengajarnya sudah tidak ada tetapi guru tersebut berada di luar sekolah ketika masih jam bekerja. terlebih lagi perginya itu bukan 
sebagai kegiatan keperluan sekolah atau kerjaannya.

Perilaku tidak baik atau biasa disebut perilaku kontraproduktif dapat menimbulkan konsekuensi negatif yang dapat merugikan. Perilaku kontraproduktif merupakan sesuatu hal yang menghambat pencapaian tujuan yang diinginkan, memiliki efek yang berlawanan dengan tujuan.

Perilaku menyimpang yang dilakukan oleh guru tersebut dilakukan dengan ketidaksengajaan, hal tersebut dipicu dengan peraturan yang terkait dengan absensi guru yang diharuskan pulang jam 15:00. Padahal jam mengajar guru di kota bekasi hanya sampai pukul 13:00. Hal tersebutyang memicu guru berada di luar sekolah ketika jam mengajarnya sudah tidak ada tetapi masih pada jam kerja.

Di indonesia, perilaku kerja kontraproduktif yang terjadi di kalangan pegawai pemerintahan terkait erat dengan disiplin Pegawai Negeri Sipil. Dalam Peraturan Pemrintah Republik Indonesia Nomor 53 Tahun 2010 tentang displin Pegawai Negeri Sipil, disebutkan bahwa pelanggaran disiplin yang dilakukan oleh Pegawai Negeri Sipil (PNS) akan dijatuhi hukuman sesuai dengan tingkat dan jenis disiplin.

Berdasarkan hal di atas dapat diketahui bahwa ketika suatu keputusan diambil untuk dijadikan sebuah aturan, itu akan mempengaruhi kebiasaan yang dilakukan oleh individu tersebut seperti halnya perilaku.

Berdasarkan uraian di atas, maka peneliti sangat tertarik untuk mengadakan penelitian tentang "Hubungan Antara Pengambilan Keputusan Dengan Perilaku Kontraproduktif Guru Di SMP Negeri Kota Bekasi”.

\section{Tinjauan Pustaka}

Perilaku menurut umam didefinisikan sebagai suatu sikap atau tindakan serta segala sesuatu yang dilakukan menusia, misalnya kegiatan yang dilakukan manusia dalam kehidupan sehari-hari, baik bekerja dengan giat atau malas.lebih lanjut umam menyatakan bahwa perilaku individu dalam organisasi adalah sikap dan tindakan seseorang dalam organisasi sebagai ungkapan dari kepribadian,persepsi dan sikap jiwanya yang bisa berpengaruh terhadap prestasi kerja (kinerja) dirinya dan organisasi.

$$
\text { Istilah "counterproductive }
$$

behavior" dalam terjemahan bahasa indonesia diartikan sebagai "perilaku tidak menguntungkan". Colquitt Lepine dan Wesson mengidentifikasikannya sebagai berikut,"counterproductive behavior defined as employee behaviors that intentionality hindeer organizational assomplishment".

Bahwa perilaku kontraproduktif merupakan perilaku pegawai yang dengan sengaja menghambat prestasi organisasi. Aspek kunci dalam definisi ini adalah "dengan sengaja" yakni segala sesuatu perbuatan yang merugikan organisasi yang dengan sengaja dilakukan karyawan atau anggota di dalam organisasi.

Selanjutnya menurut Kreitner dan Kincik, "counterproductive work behaviors (CWBs) are more likely in situation where supervisors are abusive and responsible for many employess". Perilaku kontraproduktif lebih sering terjadi pada situasi dimana para supervisor berlaku kasar dan bertanggungjawab pada para pegawai.

Colquitt, Lepine dan Wesson mendefinisikan

Counterproductive behaviors are employee behaviors that intentionally hinder organizational goal accomplishment. Examples of counterproductive behavior include sabotage, theft, wasting resources, substance abuse, gossiping, incivility, harassment, and abuse. 
Perilaku kontraproduktif adalah perilaku karyawan yang dengan sengaja menghambat pemenuhan tujuan organisasi. Contoh-contoh perilaku kontraproduktif meliputi sabotase,mencuri pemborosansumber daya, penyalahgunaan substansi, bergosip, ketidaksopanan, pelecehan, dan kekerasan.

Pengambilan keputusan merupakan kegiatan inti organisasi. Dalam organisasi kita akan terlibat dalam pengambilan keputusan, dan tentunya kita berharap dapatmembuat keputusan yang efektif.

Stephen P.Robbins dan Timothy A. Judge mengatakan "decision making occurs as a reaction to a problem". Pengambilan keputusan terjadi sebagai reaksi terhadap masalah, yaitu perbedaan yang ada antara keadaan saat ini dan beberapa keadan yang diinginkan, membutuhkan seseorang untuk mempertimbangkan alternatif tindakan, keputusan dan kualitas keputusan yang dibuat sangat dipengaruhi dari informasi dan persepsi mereka, dengan demikian pengambilan keputusan individu merupakan bagian penting dalam perilaku organisasi.

Grifin mendefinisikan pengambilan keputusan sebagai berikut "decision making is choosing one alternative from among several". Pengambilan keputusan adalah memilih satu alternatif diantara beberapa alternatif lainnya. Pemilihan alternatif didasarkan pada apa yang dipahami dan berorientasi pada tujuan yang diinginkan dicapai serta adanya keyakinan bahwa alternatif yang dipilih akan menghasilkan hasil terbaik.

Sedangkan Suzanna C. Janasz, Karen, dan Beth menjelaskan definisi:pengambilan keputusan sebagai berikut "decision making is a process by which several possibilities are considered and prioritized, resulting in a clear choice of one option over other". Pengambilan keputusan didefinisikan sebagai proses dimana beberapa kemungkinan dipertimbangkan dan diprioritaskan, sehingga menghasilkan salah satu pilihan yang jelas diantara pilihan yang lain. Dalam hal ini proses mengidentifikasi dan memilih diantara peluang yang potensial sehingga membantu dalam memecahkan masalah secepat mungkin dan membuat masalah yang mungkin terjadi pada masa yang akan datang akan lebih mudah dikelola. Pengambilan keputusan berkaitan dengan pemecahan masalah sebagaimana dikemukakan oleh Gegory Moorhead dan Ricky W. Griffin, "problem solving is a from of devision making in which the issue is unique and alternatives must be developed and evaluated whout the aid of a programmed decisions rule". Pemecahan masalah adalah suatu bentuk pengambilan keputusan dimana masalah ini adalah unik dan alternatif harus dikembangkan dengan dievaluasi tanpa bantuan suatu aturan keputusan yang terprogram.

\section{Metodelogi Penelitian}

Penelitian ini dilaksanakan di SMP Negeri se-Kota Bekasi. Penelitian ini dilaksanakan mulai bulan September sampai bulan Desember 2016.

Metode penelitian yang digunakan dalam penelitian ini adalah metode survei dengan studi korelasional. Dalam rancangan survei, peneliti mendeskripsikan secara kuantitatif (angka-angka) yang melakukan pengolahan data dengan menggunakan perhitungan statistik. Hasil penelitian menggunakan metode survei dapat digeneralisasikan dengan cara pengambilan sampel. Penelitian metode survei bertujuan mendapatkan data dari tempat yang alamiah (bukan buatan), dengan melakukan pengumpulan data untuk mendeteksi bagaimana variasivariasi pada sektor yang berkaitan dengan variasi-variasi pada satu atau 
lebih faktor lain berdasarkan pada koefisien korelasi. Penelitian ini mengambil dua variabel yaitu Pengambilan Keputusan sebagai variabel $\mathrm{X}$, dan Perilaku Kontraproduktif sebagai variabel $\mathrm{Y}$.

Dalam penelitian yang menggunakan metode survei, maka populasi dan sampel yang menjadi subjek penelitian. Populasi adalah keseluruhan subjek penelitian diartikan sebagai wilayah generalisasi yang terdiri atas obyek atau subyek yang mempunyai kualitas dan karakteristik tertentu yang ditetapkan oleh peneliti untuk dipelajari dan kemudian ditarik kesimpulannya. Adapun populasi terjangkau dalam penelitian ini adalah Guru SMP Negeri Pegawai Negeri Sipil (PNS) di Kota Bekasi dengan jumlah 1403.

Sedangkan sampel adalah sebagian atau wakil populasi yang diteliti. Berdasarkan populasi terjangkau tersebut, maka dapat diambil sampel sebanyak 94 guru. Dalam penelitian ini, sampel diambil secara acak menggunakan teknik simple random sampling. Untuk menentukan ukuran sampel, peneliti menggunakan rumus Slovin

Setelah dilakukan perhitungan uji validitas dengan sampel sebanyak 20 guru dan jumlah butir pernyataan sebanyak 40 dengan taraf signifikansi $\alpha$ $=0,05$ serta rtabel sebesar 0,444, maka dari variabel $X$ pengambilan keputusan diperoleh sebanyak 37 butir soal valid dan 3 butir soal drop. Sedangkan variabel $\mathrm{Y}$ perilaku kontraproduktif diperoleh sebanyak 35 butir soal valid dan 5 butir soal drop.

Pengukuran realibilitas terhadap variabel $\mathrm{X}$ dan $\mathrm{Y}$ akan memperoleh hasil berupa angka dan tingkat hubungan yang menyatakan tinggi atau rendahnya reliabilitas. Setelah dilakukan perhitungan reliabilitas variabel $X$ yaitu pengambilan keputusan diperoleh rhitung sebesar 0,985 dengan jumlah sampel sebanyak 20 pegawai, maka instrumen variabel $\mathrm{X}$ yaitu pengambilan keputusan dikatakan reliabel. Sedangkan dari hasil perhitungan reliabilitas variabel $Y$ yaitu perilaku kontraproduktif, diperoleh rhitung sebesar 0,969 dengan jumlah sampel sebanyak 20 pegawai, maka instrumen variabel Y yaitu perilaku kontraproduktif dikatakan reliabel.

\section{Hasil dan Pembahasan}

Karakteristik Berdasarkan Jenis Kelamin. Guru yang menjadi sampel dalam penelitian ini berjumlah 94 guru yang terdiri dari guru SMP Negeri 1 Kota Bekasi, SMP Negeri 2 Kota Bekasi, SMP Negeri 3 Kota Bekasi, SMP Negeri 4 Kota Bekasi, SMP Negeri 18 Kota Bekasi, SMP Negeri 16 Kota Bekasi dan SMP Negeri 33 Kota Bekasi. Dari 94 orang guru terdiri dari 20 orang guru berjenis kelamin laki-laki atau sebesar $21,28 \%$ dan 74 orang guru perempuan atau sebesar $78,72 \%$.

Karakteristik Berdasarkan Usia. Guru yang menjadi responden penelitian jika digolongkan berdasrkan usia maka terbagi menjadi beberapa rentang usia. Untuk rentang usia 26-29 tahun sebanyak 3 orang guru atau sebesar $3,19 \%$, usia 30-33tahun sebanyak 1 orang guru atau sebesar $1,06 \%$, usia 3437 tahun sebanyak 6 orang guru atau sebesar 6,38 \%, usia 38-41 tahun sebasar 6 orang guru atau sebesar 6,38 $\%$, usia 42-45 tahunsebanyak 16 orang guru atau sebesar $17,02 \%$, usia $46-49$ tahun sebanyak 19 orang guru atau sebesar 20,21\%, usia 50-53 tahun sebanyak 29 orang guru atau sebesar $30,85 \%$, dan usia 54-57 tahun sebanyak 14 orang guru atau sebesar $14,89 \%$.

Karakteristik Berdasarkan Pendidikan Terakhir. Guru yang menjadi responden dalam penelitian ini jika digolongkan berdasarkan pendidikan terakhirnya, terdiri dari 75 orang guru lulusan S1atau sebesar 75,79\% dan 19 
orang guru lulusan dari S2 atau sebanyak $20,21 \%$.

Deskripsi Data Variabel Pengambilan Keputusan. Sesuai dengan indikator yang di teliti, digunakan angket dengan 37 item pertanyaan yang sebelumnya telah dilaksanakan uji validitas dan reabilitas mengenai variabel pengambilan keputusan yang telah dijawab oleh para responden yaitu guru SMP Negeri Kota Bekasi. Berdasarkan hasil angket pengambilan keputusan tersebut di peroleh data dari 94 Guru yang menjadi sampel, didapat skor tertinggi yaitu 176 dan skor terendah 97, dengan perolehan skor rata-rata 147,45 dan simpangan baku sebesar 15,10 .

Berdasarkan pengujian data dalam tabel distribusi frekuensi dapat di ketahui bahwa dari 94 responden terdapat 42 guru yang mendapat skor dibawah rata - rata atau sebesar $45 \%$ dan terdapat 52 guru yang mendapat skor di atas rata - rata atau $55 \%$. Berdasarkan grafik, dapat diketahui bahwa frekuensi tertinggi pada rentang batas kelas 146,5 - 156,5 sedangkan frekuensi terendah pada rentang batas kelas 106,5-116,5.

Berdasarkan data di lapangan, maka dapat disimpulkan bahwa nilai rata - rata pengambilan keputusan di kategorikan pada kategor sedang. Hal ini dapat dilihat dari 94 guru, sebagaian besar mendapat skor 133 - 161, yakni sebanyak 67 guru.

Deskripsi Data Variabel Perilaku Kontraproduktif. Sesuai dengan indikator yang di teliti, digunakan angket dengan 35 item pertanyaan yang sebelumnya telah dilaksanakan uji validitas dan reabilitas mengenai variabel perilaku kontraproduktif yang telah diisi oleh kepala sekolah sebagai penilaian ke para responden yaitu guru SMP Negeri Kota Bekasi. Berdasarkan hasil angket pengambilan keputusan tersebut di peroleh data dari 94 Guru yang menjadi sampel, didapat skor tertinggi yaitu 155 dan skor terendah 79 , dengan perolehan skor rata-rata 121,55 dan simpangan baku sebesar 18,33.

Berdasarkan pengujian data dalam tabel distribusi frekuensi dapat di ketahui bahwa dari 94 responden terdapat 37 guru yang mendapat skor dibawah rata - rata atau sebesar $39 \%$ dan terdapat 57 guru yang mendapat skor di atas rata - rata atau $61 \%$. Berdasarkan grafik, dapat diketahui bahwa frekuensi tertinggi pada rentang batas kelas 128,5 - 139,5, sedangkan frekuensi terendah pada rentang batas kelas 78,5 - 88,5 dan 148,5 - 158,5

Berdasarkan data di lapangan, maka dapat disimpulkan bahwa nilai rata - rata perilaku kontraproduktif di kategorikan pada kategori sedang. Hal ini dapat dilihat dari 94 guru, sebagaian besar mendapat skor $103-139$, yakni sebanyak 60 guru.

Berdasarkan pengujian normalitas yang menggunakan uji Liliefors, nilai kritis $\mathrm{L}$ dari $\mathrm{n}=94$ dengan taraf signifikasi $\alpha=0$,05adalah 0,0914 Dari skor variabel $\mathrm{X}$ diperoleh $\mathrm{L}_{0}$ $=0,0872$ dan skor $\mathrm{Y}$ diperoleh $\mathrm{L}_{0}=$ 0.0799 Nilai $\mathrm{L}_{0}$ dari kedua variabel $\mathrm{X}$ dan Y terlihat Ltabel (angka kritis) lebih besar dari $\mathrm{L}_{0}$ yang berarti bahwa sampel berasal dari populasi yang berdistribusi normal.

Dari hasil uji regresi linear antara kedua variabel dalam penelitian ini di dapat persamaan $\hat{Y}=83,30+$ $0,26 x$. Hasil perhitungan menunjukan bahwa persamaan regresi memiliki koefisien $\mathrm{a}=83,30$ dan konstanta $\mathrm{b}=$ $0,26 x$. Bila digambarkan dengan bentuk grafik persamaan linier maka tampak sebagai berikut :

Dari hasil perhitungan mengenai keberartian dan kelinieran regresi dilakukan dengan menggunakan uji $\mathrm{F}$, dan hasilnya diuraikan sebagai berikut: Hasil persamaan regresi diperoleh $F_{\text {hitung }}$ sebesar 4,41 lebih besar dari $F_{\text {tabel }}$ sebesar 3,94 $(\alpha=0,05)$, dengan demikian $\mathrm{H}_{0}$ ditolak dan $\mathrm{H}_{1}$ diterima 
yang berarti model persamaan regresi sederhana untuk $\mathrm{Y}$ dengan $\mathrm{X}$ terbukti signifikan.

Uji linearitas diperoleh nilai $\mathrm{F}_{\text {hitung }}$ sebesar 1,02 lebih kecil dari $\mathrm{F}_{\text {tabel }}$ sebesar 1,62 $(\alpha=0,05)$. Dengan demikian dapat dinyatakan bahwa model persamaan regresi sederhana untuk $\mathrm{Y}$ dengan $\mathrm{X}$ terbukti linier.

Pembahasan

Pengujian Hipotesis dan

Dalam penelitian ini, hipotesis yang dirumuskan adalah hipotesis alternatif (Ha) yang menyatakan bahwa terdapat hubungan positif antara Pengambilan keputusan dengan perilaku kontraprodktif guru SMP Negeri di Kota Bekasi. Setelah data diperoleh dan diolah dilakukan perhitungan uji koefisien korelasi untuk pengujian hipotesis menggunakan rumus korelasi Product Moment dari Karl Pearson, maka didapat koefisien korelasi (rxy) sebesar $=0,21377$. Untuk mengetahui kontribusi yang diberikan variabel $\mathrm{X}$ terhadap variabel $\mathrm{Y}$, maka dilakukan perhitungan koefisien determinasi yang menghasilkan persentase $4,57 \%$. Artinya,pengambilan keputusan memberikan kontribusi sebesar 4,57\% terhadap tinggi rendahnya perilaku kontraproduktif guru SMP Negeri di Kota Bekasi. Sedangkan, 95,43\% sisanya dipengaruhi oleh variabel variabel lain diluar pengambilan keputusan.

Hasil dari perhitungan koefisien korelasi ini dimasukkan ke dalam rumus uji transformasi $\mathrm{t}$, yang menghasilkan thitung sebesar 2,10 . Uji ini dilakukan untuk mengetahui nilai signifikansi atau keyakinan dari koefisien korelasi yang menguji keindependenan atau uji satu pihak variabel pengambilan keputusan dengan perilaku kontraproduktif melalui uji-t. Dengan taraf signifikansi $\alpha=0,05$ dan $\mathrm{dk}=92$, dari daftar distribusi untuk uji t satu pihak t0,95=1,986 Dari hasil tersebut, diperoleh nilai thitung lebih besarttabel $(2,10>1,986)$. Artinya nilai thitung berada di daerah penolakan $\mathrm{H} 0$, yang berarti H0 ditolak. Dengan demikian, hipotesis alternatif (Ha) yang menyatakan bahwa terdapat hubungan yang negatif antara pengambilan keputusan dengan perilaku kontraproduktif guru SMP Negeri di Kota Bekasi.

Penelitian ini bertujuan untuk mengetahui ada tidaknya hubungan antara pengambilan keputusan dengan perilaku kontraproduktif guru SMP Negeri di Kota Bekasi. Berdasarkan hasil penelitian bahwa hipotesis alternative (Ha) diterima dan hipotesis nihil (H0) ditolak. Oleh karena itu, berdasarkan hasil uji hipotesis tersebut, maka dapat disimpulkan terdapat hubungan yang negatif antara antara pengambilan keputusan dengan perilaku kontraproduktif guru SMP Negeri di Kota Bekasi.

Arah hubungan dalam penelitian ini adalah negatif, yakni apabila pengambilan keputusan kondusif maka perilaku kontraproduktif guru SMP Negeri di Kota Bekasi. Berlaku untuk sebaliknya. Hal ini dikarenakan pengambilan keputusan yang kondusif dapat mengurangi perilaku kontraproduktif guru dan jika perilaku kontraproduktif tinggi, itu disebabkan oleh pengambilan keputusan oleh kepala sekolah itu kondusif.

Berdasarkan perhitungan koefisien korelasi Product Moment antara pengambilan keputusan dengan perilaku kontra produktif guru SMP Negeri di Kota Bekasi diperoleh nilai $r$ sebesar 0,21377 dan hasil pengujian hipotesis dengan uji-t, diperoleh thitung sebesar2,10 untuk uji satu pihak dengan $\mathrm{dk}=92$ serta taraf signifikansi $\alpha=0,05$ dari daftar distribusi diperoleh t0,95sebesar 1,986 . Sehingga nilai thitung>ttabelatau $(2,10>1,986)$ dapat disimpulkan bahwa hipotesis alternatif (Ha) yang diajukan sebelumnya dapat diterima. Sehingga terlihat adanya hubungan yang negatif antara 
pengambilan keputusan dengan perilaku kontraproduktif guru di SMP Negeri Kota Bekasi. Maka dapat disimpulkan bahwa semakin kondusif pengambilan keputusan maka semakin rendah perilaku kontraproduktif guru.

Adapun kontribusi yang diberikan pengambilan keputusan terhadap perilaku kontraproduktif setelah melakukan perhitungan dengan uji koefisien determinasi (Kd) yaitu sebesar $4,57 \%$. Dari nilai tersebut dapat memberikan gambaran bahwa perilaku kontraproduktif kondusif dapat mempengaruhi perilaku kontraproduktif guru dalam melakukan pekerjaan, meskipun terdapat faktor - faktor lain yang dapat mempengaruhi perilaku kontraproduktif guru baik berasal dari dalam maupun dari luar individu guru itu sendiri.

Setelah peneliti mengadakan penelitian, hasil yang didapat terkait pengambilan keputusan di SMP Negeri kota Bekasi , menunjukkan bahwa pengambilan keputusan cukup baik. Hanya saja, kepala sekolah dalam merencanakan tindakan yang akan di lakukan masih kurang dalam mengamati situasi, hal ini terlihat dari skor terendah pada butir instrumen nomor ke-14 sebesar 346.

Selanjutnya, skor tertinggi yang diperoleh variabel $X$ pengambilan keputusan terdapat pada butir instrument terakhir atau ke-37 sebesar 403. Melalui skor jawaban responden pada butir ini dapat diketahui bahwa kepala sekolah memilih alternatif solusi selalu berorientasi pada kepentingan umum.

Secara keseluruhan, menurut hasil interpretasi data pengambilan keputusan tersebut, maka diperoleh data dengan kategori sedang yaitu sebagian besar mendapat skor.antara 133 - 161, yakni sebanyak 67 orang guru. Dari hasil tersebut dapat dipahami bahwa sebagian besar guru secara garis besar setuju bahwa pengambilan keputusan dipengaruhi olehtindakan yang akan dilakukan kepala sekolah dan pemilihan alternatif solusi yang berdasarkan pada kepentingan umum.

Sementara itu, hasil yang didapat terkait dengan variabel perilaku kontraproduktif guru SMP Negeri Kota Bekasi, menunjukkan bahwa perilaku kontraproduktif guru sudah cukup. Hal ini terlihat dari skor terendah pada butir instrument nomor ke-32 sebesar 277 dengan memuat pernyataan guru memasuki kelas tanpa mengucapkan salam. Hal ini menunjukkan bahwa guru tidak pernah lupa untuk mengucapkan salam pada saat memasuki ruang kelas untuk memulai pembelajaran.

Sedangkan skor tertinggipada butir instrumen nomor ke-3 sebesar 378 yang memuat pernyataan kantor guru menduplikasi RPP. Rendahnya skor tersebut menunjukkan bahwa guru sering kali menduplikasi pembuatan RPP dari guru lain yang memiliki tugas mengajar mata pelajaran yang sama.

Secara keseluruhan, menurut hasil interpretasi data perilaku kontraproduktif tersebut, maka diperoleh data dengan kategori sedang yaitu sebagian besar mendapat skor antara 103 - 139, yakni sebanyak 60 orang guru

Dari pembahasan kedua variabel di atas dan dari perhitungan uji hipotesis beserta uji koefisien determinasi maka dapat disimpulkan bahwa hasil penelitian ini menyatakan kebenaran adanya hubungan yang negatif antara pengambilan keputusan dengan perilaku kontraproduktif guru SMP Negeri di Kota Bekasi.

Dalam hal ini, sesuai dengan apa yang telah diungkapkan Dalam bukunya Charmine E. J. Härtel, at.,all Emotion,Ethics And Decision-Making Jessica Mesmer Magnus mengatakan bahwa : ...so, when and why do individuals engage in counterproductive behavior ?. a number of individual (e.g.. personality) and cotextual (e.g..job characteristic, work group characteristics, organizational culture) 
factors my predict such behavior. One unexplored variable with the potential to impect ethical behavior and decisionmaking is emotional intelligence (EI).

Individu terlibat dalam perilaku kontraproduktif dengan beberapa faktor (misalnya kepribadian) dan yang lebih konteks (karakteristik pekerjaan, karakteristik kelompok kerja,budaya organisasi) faktor yang mempengaruhi perilaku tersebut lainnya ialah. Yang belum dijelajahi perilaku etis dan pengambilan keputusan dengan impact kecerdasan emosional (EI).

Kontribusi yang diberikan oleh pengambilan keputusan terhadap perilaku kontraproduktif adalah sebesar 4,57\%. Dari hasil tersebut dapat memberikan gambaran bahwa pengambilan keputusan yang kondusif akan memberikan dapak bagi perilaku kontraproduktif. Sehingga hasil penelitian ini menyatakan kebenaran adanya hubungan antara pengambilan keputusan dengan perilaku kontraproduktif.

\section{Kesimpulan dan Implikasi}

Berdasarkan temuan penelitian yang telah diuraikan, diketahui bahwa pengambilan keputusan dengan perilaku kontraproduktif berada pada kategori rata - rata sedang. Kontribusi pengambilan keputusan terhadap perilaku kontraproduktif adalah sebesar $4,57 \%$ yang membuktikan bahwa semakin kondusif pengambilan keputusan, maka semakin rendah pula perilaku kontraproduktif guru. Oleh karena itu, diperoleh kesimpulan bahwa terdapat hubungan yang negatif antara pengambilan keputusan dengan perilaku kontraproduktif guru SMP Negeri di Kota Bekasi.

\section{Daftar Pustaka}

A.Judge, S. P. (2010). Organizational Behavior. New Jersey: PrenticeHall.
A.Locke, E. (2009). The Blackwell Handbook of Principal of Organizational Behavior. West Sussex: Jhon Wiley \& sons,ltd.

Andre, Rae. (2008). Organizational Behavior. USA: Pearson Education

Anzizhari, S. (2004). Sistem Pengambilan Keputusan. Jakarta: Grasindo.

Arikunto, S. (2010). Prosedur Penelitian Suatu Pendekatan Praktik. Jakarta: Rineka Cipta.

Chermine E.J Hartler, W. Z. (2008). Emotion,Ethics and decission making. Uk: Emerald Group Publishing limited.

Geogre Moorhed and Ricky W, G. (2010). Organizational Behavior. Canada: Nelson education.

Glinow, S. L. (2005). Organizational Behavior,Emergining Realities For The Workplace Revolution. New York: McGraw-Hill.

Jason A. Colquitt, J. A. (2009). Organization Behavior. New York: Megraw-Hill Irwin.

Jason A.Colquitt, J. A. (2011). Organizational Behavior, Improving Performance and Commitment in The Work place. New York: Mcgraw-Hill.

Kinciki, R. K. (2010). Organizational Behavior. New York: McGrawHill.

Robbins, S. P. (2011). Organizational behavior. New Jersey: Person Educational.

Stephen P. Robbins, M. C. (2012). Management-11th. New Jersey: Prentice-Hall.

Sudjana. (2005). Metode Statistik. Bandung: Trasito. 
Sugiona. (2013). Metode penelitian Pendidikan: Pendekatan Kuantitatif, Kualitatif dan R\&D. Bandung: Alfabeta.

Umam, K. (2010). Perilaku Organisasi. Bandung: Pustaka Setia.
Umar, H. (2003). Metode Riset Bisnis. Jakarta: Gramedia.

Zuriah, N. (2006). Metodologi

Penelitian Sosial dan

Pendidikan. Jakarta: Bumi Aksara 